Бурченя О. П. [1; ORCID ID: 0000-0002-5424-3951], здобувач вищої освіти третього (освітньо-наукового) рівня

${ }^{1}$ Національний університет водного господарства та природокористування, м. Рівне

\title{
СТРАТЕГІЧНЕ УПРАВЛІННЯ РЕДАКЦІЯМИ ГАЗЕТ НА ОСНОВІ ВЕБАНАЛІТИКИ
}

Ключовим моментом стратегічного управління редакцією $є$ процес, який базується на механізмі завчасного прогнозування напрямів подальшого розвитку редакції в бізнес-середовищі. У статті проаналізовано регіональний ринок ЗМІ 3 точки зору використання вебаналітики. Автор приходить до висновку, що вагома частка учасників цього ринку недостатньою мірою використовує у своїй діяльності механізми стратегічного управління на основі вебаналітики. У пропонованому дослідженні здійснено спробу окреслити набір необхідного інструментарію, який допоможе редакціям друкованих та електронних видань отримати дані для аналізу і моніторингу уподобань читача. Водночас розглянуто стандарти вебаналітики, проаналізовано сучасні вебсистеми, які використовуються в інформаційно-аналітичній діяльності ЗМІ задля впевненості, що вони не лише продукують контент, але $\mathrm{i}$ його зміст доходить до читачів. Застосування вебаналітики є потрібним для використання редакціями друкованих та електронних ЗМІ 3 метою подальшого просування продукту на ринку преси. Значимість цього дослідження полягає у розумінні важливості використання даних веб-аналітики для успішної роботи мас-медіа.

Ключові слова: стратегічне управління; інформація; вебаналітика; вебсайт; відвідувачі; аудиторія; ринок преси.

Актуальність дослідження. У сучасних умовах суспільного розвитку інформація $\epsilon$ важливим ресурсом, яка продукується засобами масової інформації, в тому числі й газетами, і є продуктом діяльності редакцій. У системі менеджменту діяльності редакції газет використовують стратегічне управління як процес, за допомогою якого здійснюється довгострокове керування, визначаються специфічні цілі діяльності, розробляються стратегії для досягнення цих цілей, враховуючи всі релевантні (найістотніші) зовнішні та внутрішні фактори, а також забезпечують виконання розроблених відповідних планів, які постійно розвиваються і змінюються [1].

Розуміння важливості стратегічного підходу до управління викликає суттєвий попит у редакцій на обґрунтовані теоретичні 
концепції стратегічного управління, а також ефективні інструменти і методи розробки і реалізації стратегії. Ключовим моментом стратегічного управління редакцією $є$ процес, який базується на механізмі завчасного прогнозування напрямів подальшого розвитку редакції в бізнес-середовищі. Це вимагає розробки і впровадження нових дієвих механізмів стратегічного управління і в першу чергу механізмів управління стратегічними змінами.

Аналіз останніх досліджень і публікацій. Традиційно першими розробниками теорії стратегічного управління вважаються такі західноєвропейські вчені, як Д. Шендел, К. Хатт, Ф. Котлер. Проблеми стратегічного управління компанії вивчали відомі вітчизняні та закордонні вчені. Значний внесок у дослідження стратегічного управління зробили: $€$. І. Данільова [2], Ю. М. Мельник [3], Л.В. Пан [3], Г.Ю. Гедройц [4] та ін. Проте в Україні вчені та практики не досить уваги приділяють стратегічному управлінню, зосереджуючи основну увагу на фінансових результатах - отриманні прибутку й управлінні активами та пасивами компанії, а осторонь залишають підходи до формування процесів отримання цих результатів у високо турбулентних умовах сучасності.

Постановка завдання. Головним у діяльності редакцій газет $\epsilon$ вивчення поведінки свого читача, його інтересів і змін, що відбуваються у його смаках, а на основі цього вибудовування стратегічних планів та знаходження шляхів їх виконання.

Виклад основного матеріалу дослідження. Побудова стратегічних планів діяльності редакцій газет $\epsilon$ складовою управління і розпочинається із ґрунтовного аналізу внутрішнього і зовнішнього середовища, яке потенційно може слугувати передумовою до досягнення фінансової стабільності [5]. Внутрішнє середовище діяльності редакцій газет формує ціла сукупність факторів, а саме: організаційна структура, персонал, оборотні кошти, інноваційні можливості, витрати і прибуток. Серед зовнішніх законодавча політика в галузі 3МІ, податкова політика держави, інноваційно-інвестиційна політика, читацька аудиторія, конкурентне середовище, рекламодавці, друкарські послуги. I якщо редакції можуть управляти внутрішніми факторами, то зовнішні - задають межі діяльності, і редакції на них не впливають, а повинні лише враховувати при реалізації стратегічного управління.

Якщо користуватися таким підходом до управління діяльністю редакцій газет, то можна стверджувати, що воно у майже $5 \%$ редакцій $€$ незадовільним, про що свідчить динаміка кількості друкованих назв газет та загального тиражу впродовж дворічного періоду. Адже сама така кількість зникаючих назв газет, $10 \%$ 
скорочення загального тиражу примірників, отже, припинення їх діяльності як збиткових (табл. 1).

Таблиця 1

Кількість друкованих назв газет в Україні та загального тиражу [6]

\begin{tabular}{|c|c|c|c|c|}
\hline \multirow{2}{*}{ Види видань } & \multicolumn{3}{|c|}{ Кількість назв } & \multicolumn{2}{|c|}{$\begin{array}{l}\text { Загальний тираж } \\
\text { примірників, тис. } \\
\text { прим. }\end{array}$} \\
\cline { 2 - 5 } & 2018 & 2019 & 2018 & 2019 \\
\hline Газети & 1736 & 1651 & 1827295,5 & 1478147 \\
\hline
\end{tabular}

Окрім того, самі журналісти газет оцінюють таку динаміку, як закономірний процес переходу від друкованого варіанту випуску газет до онлайн-формату, що забезпечує велику економію витрат на макетуванні, розповсюдженні, оптимізації робочих місць та заробітних плат, економії паперу. Проте, посилаючись на досвід країн з ринковою економікою (США, Німеччина), є думка, що місцеві газети будуть існувати та навіть виходити у друкованому форматі, але стануть більш нішевими та якісними. Головним для існування газети має стати їі бренд, що забезпечує тривалість зв'язку, а саме спілкування між газетою і їі читачами, бо електронний формат $\epsilon$ поверхневим і цього не може забезпечити читачеві. Гравці ринку друкованих місцевих засобів інформації наголошують, що в Україні існує проблема культури передплати, доставки і розповсюдження преси (газет) до читача. В Україні низька якість передплати періодичних видань. У даному контексті важливим є досвід США, де 90\% 3МІ розповсюджується через передплату і лише $10 \%$ через відкритий продаж [7].

Звісно, що можливості інтернету забезпечують швидкість отримання споживачем інформації та змушують редакції газет формувати вебсайти газет. Незалежно від формату випуску у світ газети, їі редакція зорієнтована на прибуткову чи беззбиткову діяльність.

Результати проведеного дослідження [8] свідчать, що на прибутковість діяльності редакцій газет впливають виключно внутрішні фактори, а політика ціноутворення на видання $\epsilon$ результатом менеджменту. Звісно, що у функціонуванні діяльності редакцій газет існують і відкриваються потенційні можливості, але їх необхідно підкріплювати якісним контентом, зорієнтованим на споживацькі інтереси. Якщо ж цього не відбувається у діяльності редакції, то так вони і залишаються лише невикористаним потенціалом прибутковості, а згодом і їі втрати. 
В умовах глобальних викликів, суттєво змінюваної ринкової ситуації, жорстокої конкуренції найефективнішим способом розвитку редакцій друкованих періодичних засобів масової інформації $\epsilon$ формування їх власної стратегії щодо зміцнення становища на ринку, здійснення не лише беззбиткової діяльності, а й отримання прибутку. Саме прибуток $€$ показником ефективності економічної діяльності редакції та іï позитивним результатом. Джерелами формування прибутку редакції газети $€$ доходи від реклами, передплати та роздрібної торгівлі газетами. Доходи від передплати та роздрібної торгівлі формуються лише за рахунок друкованого періодичного видання, тобто газети, а прибуток від реклами видання може отримувати з як з вебресурсу, так і з друкованого видання.

Як свідчать результати проведеного у січні-лютому 2020 року Інститутом демократії імені Пилипа Орлика за підтримки Медійної програми в Україні моніторингу роздержавлених регіональних друкованих медіа та їх сайтів у восьми регіонах України: Дніпропетровській, Донецькій, Житомирській, Львівській, Одеській, Сумській, Харківській, Чернівецькій областях, що низькою $\epsilon$ у реформованих українських ЗМІ якість контенту, тематика, дотримання стандартів журналістики та законодавства щодо розміщення реклами. Окрім того, високою є редакційна залежність від колишніх власників та співвласників - місцевої влади [9].

Проведено моніторинг роботи діяльності редакцій газет на локальному ринку Рівненській області. Вона не входила до переліку областей, де відбувався моніторинг сайтів газет. До дослідження були відібрані такі параметри, як потенціал діяльності редакцій місцевих (обласного і районного значення) газет, що визначався кількістю населення, що проживає на території розповсюдження друкованих примірників, а також обсягу реклами, річної передплатної ціни газети. Оцінка відібраних параметрів дає право стверджувати наступне. Між обсягами реклами і передплатною ціною не існує взаємозв'язку. Це свідчить проте, що редакції газет намагаються максимізувати доходи за рахунок усіх джерел. I якщо обсяг передплати скорочується, то намагаються зберегти доходність редакції за рахунок збільшення передплатної ціни та розміщення реклами.

У сучасних умовах редакції газет, випускаючи друкований варіант, намагаються і впроваджувати електронну версію, яку розміщують на створюваних вебсайтах. Інформацію про вебсайти друкованих засобів масової інформації обласної та районної сфер розповсюдження Рівненської області та показники їх відвідуваності та посилань на них наведено в табл. 2. 
Таблиця 2

Результати моніторингу діяльності редакцій місцевих газет Рівненської області, 2020 р. [10; 11]

\begin{tabular}{|c|c|c|c|c|c|c|c|c|c|c|}
\hline \multirow{2}{*}{ № } & \multirow{2}{*}{ Назва видання } & \multirow{2}{*}{$\begin{array}{c}\text { Кількість } \\
\text { населення, } \\
\text { осіб }\end{array}$} & \multirow{2}{*}{$\begin{array}{c}\text { Обсяг } \\
\text { реклами, } \\
\%\end{array}$} & \multirow{2}{*}{$\begin{array}{c}\text { Передплатна ціна } \\
\text { на рік, грн }\end{array}$} & \multirow{2}{*}{\multicolumn{2}{|c|}{ Наявність і назва сайту }} & \multicolumn{2}{|c|}{$\begin{array}{l}\text { Відвідуваність за } \\
\text { місяць, од. }\end{array}$} & \multicolumn{2}{|c|}{$\begin{array}{c}\text { Посилання на } \\
\text { сайт }\end{array}$} \\
\hline & & & & & & & $\begin{array}{c}\text { перег- } \\
\text { ляди }\end{array}$ & $\begin{array}{l}\text { відві- } \\
\text { дувачі }\end{array}$ & $\begin{array}{l}\text { сторі- } \\
\text { нок }\end{array}$ & $\begin{array}{l}\text { доме- } \\
\text { нів }\end{array}$ \\
\hline 1 & 2 & 3 & 4 & 5 & 6 & 7 & 8 & 9 & 10 & 11 \\
\hline \multicolumn{11}{|c|}{ Обласна сфера розповсюдження } \\
\hline & 1. Рівне вечірнє, м. Рівне & \multirow{6}{*}{1152961} & 30 & 252,0 & + & https://rivnepost.rv.ua/ & 168000 & 42000 & 13965 & 1032 \\
\hline & ОГО, м. Рівне & & 35 & 236,64 & + & http://ogo.ua/ & 107000 & 26700 & 1899241 & 1868 \\
\hline & $\begin{array}{c}\text { Вісті Рівненщини, } \\
\text { м. Рівне } \\
\end{array}$ & & 10 & 321,96 & + & http://www.visti.rovno.ua/ & 65600 & 16400 & 440 & 89 \\
\hline & Сім днів, м. Рівне & & 20 & 267,60 & + & https://7dniv.rv.ua/ & 25600 & 6380 & - & - \\
\hline & 5. Рівне-ракурс, м. Рівне & & 20 & 177,96 & + & http://rakurs.rovno.ua/ & 7301 & 5620 & 20106 & 208 \\
\hline & 6. Вільне слово, м. Рівне & & 20 & 288,0 & + & http://vilneslovo.rv.ua/ & 4560 & 1137 & 44 & 14 \\
\hline \multicolumn{11}{|c|}{ Районна сфера розповсюдження } \\
\hline 7. & $\begin{array}{c}\text { Володимирецький вісник, } \\
\text { м. Володимирець }\end{array}$ & 65501 & 15 & 375,72 & $\begin{array}{l}+ \\
+\end{array}$ & $\begin{array}{c}\underline{\text { http://polissya.net/ }} \\
\underline{\text { https://volodymyrets.city/ }}\end{array}$ & $\begin{array}{l}20000 \\
21800\end{array}$ & $\begin{array}{l}5000 \\
5430\end{array}$ & $\begin{array}{l}3567 \\
298\end{array}$ & $\begin{array}{l}78 \\
75\end{array}$ \\
\hline 8. & $\begin{array}{c}\text { Сурми Радзивилів } \\
\text { м. Радивилів }\end{array}$ & 36435 & 20 & 272,76 & + & https://syrmu.com.ua/ & 17387 & 5764 & 30 & 17 \\
\hline 9. & Вісник Кореччини м. Корець & 32553 & 30 & 250,80 & + & $\underline{\text { http://korec.gz.org.ua/ }}$ & 15700 & 3920 & - & - \\
\hline
\end{tabular}


продовження табл. 2

\begin{tabular}{|c|c|c|c|c|c|c|c|c|c|c|}
\hline 10. & Нове життя, с. Здолбунів & 56109 & 20 & 240,00 & + & http://newlife.rv.ua/ & 9030 & 2259 & 319 & 69 \\
\hline 11. & Життя і слово, м. Остріг & 27744 & 10 & 279,72 & + & http://zhislovo.rv.ua/ & 8580 & 2150 & 21 & 16 \\
\hline 12. & $\begin{array}{c}\text { Новини Рокитнівщини, } \\
\text { смт Рокитне }\end{array}$ & 58223 & 15 & $\begin{array}{l}230,12 / \\
11 \text { міс }\end{array}$ & + & http://novinyrokytno.do.am/ & 6390 & 1599 & - & - \\
\hline 13. & $\begin{array}{c}\text { Сарненські новини, } \\
\text { м. Сарни }\end{array}$ & 104037 & 25 & 360,00 & + & http://sarnynews.in.ua/ & 6001 & 3352 & 44 & 20 \\
\hline 14. & $\begin{array}{l}\text { Дубровицький вісник, } \\
\text { м. Дубровиця }\end{array}$ & 46727 & 20 & 256,08 & + & $\frac{\text { http://dubrvisnik.blogspot.co }}{\underline{\mathrm{m} /}}$ & - & - & 28 & 5 \\
\hline 15. & Рідний край, смт Гоща & 34401 & 40 & 260,88 & + & http://www.rayonka.pp.ua/ & - & - & - & - \\
\hline 16. & $\begin{array}{l}\text { Вісник Демидівщини, } \\
\text { смт Демидівка }\end{array}$ & 14057 & - & 284,84 & - & - & - & - & - & - \\
\hline 17. & Замок, м. Дубно & 44352 & - & 197,28 & - & - & - & - & - & - \\
\hline 18. & $\begin{array}{c}\text { Надслучанський вісник, } \\
\text { м. Березне }\end{array}$ & 63716 & 20 & 284,16 & - & - & - & - & - & - \\
\hline 19. & $\begin{array}{c}\text { Новини Костопільщини, } \\
\text { м. Костопіль }\end{array}$ & 63462 & 10 & 275,16 & - & - & - & - & - & - \\
\hline 20. & Гомін і К, смт Млинів & 36771 & 15 & 272,88 & - & - & - & - & - & - \\
\hline 21. & $\begin{array}{c}\text { Прапор перемоги, } \\
\text { м. Радивилів } \\
\end{array}$ & 36435 & 10 & 260,76 & - & - & - & - & - & - \\
\hline 22. & Слово і час, м. Рівне & 92981 & 20 & 224,40 & - & - & - & - & - & - \\
\hline 23. & Полісся, смт Зарічне & 34722 & 20 & 354,00 & - & - & - & - & & \\
\hline
\end{tabular}


Отож, із 23 друкованих видань Рівненської області мають свій вебресурс 15 або ж 2/3. Проте, у половини щодо відвідуваності газет сайт є малофункціональними, а у 13,3\% - взагалі нефункціональним.

Проте, наявність сайту дозволяє суттєво розширити читацьку аудиторію. Якщо порівнювати газети обласного розповсюдження «Рівне-ракурс», «Вільне слово», то відвідуваність їх сайтів досить низька у порівнянні з іншими виданнями навіть районної сфери розповсюдження. Отже, є всі підстави стверджувати, що ці видання недостатньо використовують свої вебресурси.

Економічно грамотно сформована стратегія розвитку редакцій друкованих засобів масової інформації дозволить їм стабільно отримувати прибуток від своєї господарської діяльності, що матиме вплив на їх подальший сталий розвиток.

Звісно, що процес інформатизації суспільства та темп змін обумовив трансформацію діяльності редакцій газет. Вони розпочали створювати і розвивати сайти газет, використовуючи всесвітню мережу Інтернет, який $є$ найкращим джерелом для максимальної реалізації комунікативних можливостей мас-медіа зі своє аудиторією, завдяки розміщенню інформації, що миттєво стає надбанням мільйонів читачів. В режимі реального часу, аудиторія може оцінити тексти, копіювати і поширювати їх у соціальних мережах (Twitter, Facebook та ін.), зв'язуватися з автором публікації, дискутувати та обговорювати опублікований матеріал тощо. Завдяки винятковості вебпростору, можливості онлайн-ЗМІ практично безмежні: цілодобове оновлення новин, доступність і зручність перегляду сайтів ЗМІ на різних електронних носіях.

Важливою перевагою інтернет-ЗМІ $€$ те, що дає можливість редакції самостійно (без допомоги соціологічних опитувань) вивчати свого читача, його смаки і потреби. Це можна зробити не лише через спілкування з аудиторією, через редакційні чати, форуми, соціальні мережі, а й за допомогою інструментів вебаналітики [12]. Вебаналітика (Web analytics) - це спостереження і збір даних про те, хто і яким чином відвідує сайт газети, а також аналіз отриманих даних.

Як стверджується в джерелі [12], системний аналіз діяльності інтернет-ЗМІ України за допомогою інструментів вебаналітики $\epsilon$ актуальним, важливим, адже може дати відповіді на різні питання, щодо вдосконалення ресурсу, покращення контенту, вибору важливих тем тощо. Вебаналітика - це своєрідна підказка для керівництва редакції ЗМІ як потрібно розвивати і вдосконалювати інтернет-ресурс. 
Редакції повинні вибудовувати стратегію, яка дозволила б адаптуватися до змін, що відбуваються у зовнішньому середовищі ринку засобів масової інформації та використати їх у внутрішньому середовищі для нарощування прибутковості своєї діяльності.

Таким джерелом формування прибутковості $\epsilon$ добре наповнений вебсайт друкованого засобу, який має високу відвідуваність і посилання, що $є$ наслідком існування попиту як у населення, так і у рекламодавців. Створення вебресурсу друкованого засобу масової інформації дозволяє оптимізувати витрати, підвищувати упізнаваність бренду, розширювати читацьку аудиторію та утримувати читача, охоплювати більшу частину ринку медійної продукції, залучати рекламу, отримувати більший прибуток.

Сайт - це своєрідне онлайн-представництво газети, яке $€$ ї̈ доповненням та дозволяє медіа:

- працювати в форматі оперативного видання і оприлюднювати інформацію без «прив'язки» до графіку друку;

- оприлюднювати пресі мультімедійні матеріали, відео;

- підтримувати зв'язок із читачами, враховувати їх побажання щодо контенту;

-досягати розширення аудиторії (підвищення трафіку, збільшення географії читацької аудиторії), в тому числі із комерційною метою.

Через соціальні групи у Фейсбук друковані видання поширюють більшість своїх матеріалів та намагаються якомога оперативно ділитися свіжими новинами. Саме такі методи роботи дозволяють не відставати від сучасних тенденцій ринку медіа. Варто зазначити, що переважна більшість редакцій впроваджує новітні технології роботи з власної ініціативи та засадах самофінансування.

У системах вебаналітики збирається інформація про покази, кліки, перегляди, про поведінку відвідувачів сайту, сторінок, що дозволяє виявити сферу зацікавленості інформацією, джерела трафіку, які залучають користувачів на сайт.

Застосування вебаналітики дозволяє проаналізувати читацьку аудиторію як за віковою приналежністю, так і географічною, іï вподобання, відвідуваність сайту, кількість посилань на сайт, джерела трафіку, тощо і тим самим збільшити свій фінансовий результат - прибуток. Економічно грамотно сформована стратегія розвитку редакцій друкованих засобів масової інформації дозволить їм стабільно отримувати прибуток від своєї господарської діяльності, що матиме вплив на їх подальший сталий розвиток.

Висновки 3 проведеного дослідження. Сучасний формат діяльності редакцій газет обумовлює застосування комплексу 
інструментів стратегічного управління заради ведення ними прибуткової діяльності. Вони вибудовують плани діяльності, спираючись на можливості вебаналітики, яка допомагає краще пізнати їм свого споживача готової продукції (газети). Проведення дослідження свідчить, що доповнення, а подекуди й альтернативу друкованому формату вони уже створили у формі онлайн-газети, що розміщується на сайті, але ще не забезпечують його ефективну роботу, про що свідчить низька відвідуваність і мала кількість переходів на сайт.

1. Шершньова 3. Є. Стратегічне управління : підручник. 2-ге вид., перероб. і доп. Київ: КНЕУ, 2004. 699 с. 2. Данільова Є. І. Взаємозв'язок стратегічного та оперативного управління в системі управління компанією. Економіка. Соціологія. Менеджмент. 2009. № 4. С. 24-27. 3. Пан Л. В. Збалансована система показників (BALANCED SCORECARD - BSc) як інструмент ефективного управління стратегією організації. Наукові записки. 2010. № 21. С. 56-63. 4. Гедройц Г. Ю. Визначення сутності поняття «стратегічне управління». Економічні науки/10 Економіка підприємства. 2012. № 2. С. 22-23. 5. Сергій Ксьондз. Визначення та обґрунтування факторів, що формують середовище підприємницької діяльності. URL: http://econom.chnu.edu.ua/wp-content/uploads/2016/10/ksjondz-9.pdf (дата звернення: 01.11.2020). 6. Статистика. URL: http://www.ukrbook.net/statistika_.html. (дата звернення: 31.10.2020). 7. Українську пресу вбили пошта та інтернет: коли зникнуть друковані газети. URL: https://dyvys.info/2019/12/02/ukrayinsku-presuvbyly-poshta-ta-internet-koly-znyknut-drukovani-gazety/ (дата звернення: 30.10.2020). 8. Безтелесна Л.І., Пляшко О.С., Бурченя О.П. Оцінка впливу конкуренції на діяльність редакцій місцевих комунальних друкованих засобів масової інформації. Бізнес Інформ. 2017. № 6. С. 55-61. 9. Редакційна залежність та інтернет-слабкість реформованих українських ЗМІ - аналітичний звіт за січеньлютий 2020 року (друковані видання). URL: https://idpo.org.ua/reports/3317redakcijna-zalezhnist-ta-internet-slabkist-reformovanix-ukra\%d1\%97nskix-zmi-

analitichnij-zvit-za-sichen-lyutij-2020-roku-drukovani-vidannya.html (дата звернення: 30.10.2020). 10. Сервіс аналізу сайтів. URL: https://a.pr-cy.ru/ (дата звернення: 31.10.2020). 11. Періодичні видання України. Укрпошта : офіційний веб портал. URL: https://www.ukrposhta.ua/ua/periodychni-vydannia (дата звернення: 01.11.2020). 12. Мудра І. Веб-аналітика як важлива складова успішного функціонування 3МІ в Інтернеті. Вісник Національного університету «Львівська політехніка». Сер. Журналістські науки. 2018. № 896. С. 117-126. URL: ttp://nbuv.gov.ua/UJRN/vnulpjn_2018_896_18 (дата звернення: 02.11.2020).

\section{REFERENCES:}

1. Shershnova Z. Ye. Stratehichne upravlinnia : pidruchnyk. 2-he vyd., pererob. i dop. Kyiv : KNEU, 2004. 699 s. 2. Danilova Ye. I. Vzaiemozviazok stratehichnoho ta operatyvnoho upravlinnia v systemi upravlinnia kompaniieiu. Ekonomika. Sotsiolohiia. Menedzhment. 2009. № 4. S. 24-27. 3. Pan L. V. Zbalansovana systema pokaznykiv (BALANCED SCORECARD - BSc) yak instrument efektyvnoho upravlinnia stratehiieiu orhanizatsii. Naukovi zapysky. 2010. № 21. S. 56-63. 4. Hedroits H. Yu. Vyznachennia sutnosti poniattia «stratehichne upravlinnia». Ekonomichni nauky/10 Ekonomika 
Серія «Економічні науки»

Випуск 4(92) 2020 p.

pidpryiemstva. 2012. № 2. S. 22-23. 5. Serhii Ksondz. Vyznachennia ta obgruntuvannia faktoriv, shcho formuiut seredovyshche pidpryiemnytskoi diialnosti. URL: http://econom.chnu.edu.ua/wp-content/uploads/2016/10/ksjondz-9.pdf. (data zvernennia: 01.11.2020). 6. Statystyka. URL: http://www.ukrbook.net/statistika_.html. (data zvernennia: 31.10.2020). 7. Ukrainsku presu vbyly poshta ta internet: koly znyknut drukovani hazety. URL: https://dyvys.info/2019/12/02/ukrayinsku-presuvbyly-poshta-ta-internet-koly-znyknut-drukovani-gazety/ (data zvernennia: 30.10.2020). 8. Beztelesna L. I., Pliashko O. S., Burchenia O. P. Otsinka vplyvu konkurentsii na diialnist redaktsii mistsevykh komunalnykh drukovanykh zasobiv masovoi informatsii. Biznes Inform. 2017. № 6. C. 55-61. 9. Redaktsiina zalezhnist ta internet-slabkist reformovanykh ukrainskykh ZMI - analitychnyi zvit za sichen-liutyi 2020 roku (drukovani vydannia). URL: https://idpo.org.ua/reports/3317-redakcijnazalezhnist-ta-internet-slabkist-reformovanix-ukra\%d1\%97nskix-zmi-analitichnij-zvitza-sichen-lyutij-2020-roku-drukovani-vidannya.html (data zvernennia: 30.10.2020). 10. Servis analizu saitiv. URL: https://a.pr-cy.ru/ (data zvernennia: 31.10.2020). 11. Periodychni vydannia Ukrainy. Ukrposhta : ofitsiinyi veb portal. URL: https://www.ukrposhta.ua/ua/periodychni-vydannia (data zvernennia: 01.11.2020). 12. Mudra I. Veb-analityka yak vazhlyva skladova uspishnoho funktsionuvannia ZMI v Interneti. Visnyk Natsionalnoho universytetu «Lvivska politekhnika». Ser. Zhurnalistski nauky. 2018. № 896. S. 117-126. URL: ttp://nbuv.gov.ua/UJRN/vnulpjn_2018_896_18 (data zvernennia: 02.11.2020).

Burchenia O. P. [1; ORCID ID: 0000-0002-5424-3951] Post-graduate Student

${ }^{1}$ National University of Water and Environmental Engineering, Rivne

\section{STRATEGIC MANAGEMENT OF NEWSPAPER EDITORIAL OFFICES BASED ON WEB-ANALYTICS}

Understanding the importance of a strategic approach to management causes significant demand from editors for sound theoretical concepts of strategic management, strategy development and implementation. The key point of strategic management of the editorial office is the process based on the mechanism of early forecasting of the directions of further development of the editorial office in the business environment.

This requires the development and implementation of new effective mechanisms for strategic management and, above all, mechanisms for managing strategic change in both external and internal environments. The article analyzes the regional media market in terms of the use of web analytics, and the author concludes that a significant proportion of market participants do not sufficiently use in their activities strategic management mechanisms based on web analytics.

The proposed study attempts to outline a set of necessary tools that will help the editors of print and electronic publications to obtain data for analysis and monitoring of reader preferences, as well as considered web analytics standards, analyzed modern web systems used in media information and analytical activities to ensure that they not only produce 
content, but also its content reaches readers. The use of web analytics is necessary for the use of print and electronic media in order to further promote the product in the press market.

Monitoring and analysis of the work of newspaper editorial offices in the local market of Rivne region was carried out. The article emphasizes that the main task of web analytics is to monitor site traffic, based on which the audience is determined and the behavior of visitors is studied to make decisions on the development and expansion of the functionality of the Internet resource. Therefore, the significance of this study lies in understanding the importance of using web analytics data for the successful operation of the media.

Keywords: strategic management; information; web analytics; website; visitors; audience; press market.

Бурченя Е. П. [1; ORCID ID: 0000-0002-5424-3951], соискатель высшего образования третьего (научно-образовательного) уровня

${ }^{1}$ Национальный университет водного хозяйства и природопользования, г. Ровно

\section{СТРАТЕГИЧЕСКОЕ УПРАВЛЕНИЕ РЕДАКЦИЯМИ ГАЗЕТ НА ОСНОВЕ WЕВ-АНАЛИТИКИ}

Ключевым моментом стратегического управления редакцией является процесс, основанный на механизме заблаговременного прогнозирования направлений дальнейшего развития редакции в бизнес-среде. В статье проанализированы региональный рынок СМИ с точки зрения использования веб-аналитики. Автор приходит к выводу, что значительная доля участников этого рынка в недостаточной степени использует в своей деятельности механизмы стратегического управления на основе веб-аналитики. В предлагаемом исследовании предпринята попытка очертить набор необходимого инструментария, который поможет редакциям печатных и электронных изданий получить данные для анализа и мониторинга предпочтений читателя. В то же время рассмотрены стандарты веб-аналитики, проанализированы современные веб-системы, которые используются в информационноаналитической деятельности СМИ для уверенности, что они не только производят контент, но и его содержание доходит до читателей. Применение веб-аналитики является необходимым для использования редакциями печатных и электронных СМИ с целью дальнейшего продвижения продукта на рынке прессы. Значимость этого исследования заключается В понимании важности использования данных вебаналитики для успешной работы масс-медиа.

Ключевые слова: стратегическое управление; информация; вебаналитика; сайт; посетители; аудитория; рынок прессы. 